専門医症例報告

低位咬合を伴う部分歯列欠損症例に対する補綴歯科治療の 1 例

山本 裕信

\title{
Construction of a Removable Denture for a Partially Edentulous Patient with Infraocclusion
}

Hironobu Yamamoto

抄 録

症例の概要：患者は 61 歳の男性. 臼歯部の咬耗および咬合支持減少に伴う咀嚼障害を主訴に来院した. 口腔内所見より低位咬合が疑われたため, 有床形態のスプリントを治療用義歯として応用し咬合挙上を行 うとともに, 最終義歯として咬耗部と適合する部位にアンレー型レストを応用した部分床義歯を装着した。 考察：有床形態のスプリントを治療用義歯として応用し咬合高径の挙上を行い，その情報を元に最終義歯 の咬合高径および床外形の決定を行った。その結果，患者の満足と良好な治療経過が得られたと考えられ る。また，アンレー型レストの応用により不要な支台歯形成を避けることができたと考えられる。 結論：有床形態のスプリントおよびアンレー型レストを応用した部分床義歯の装着により，良好な経過が 得られた。

和文キーワード

低位咬合，咬合高径，アンレー型レスト，部分床義歯

\section{ABSTRACT}

Patient: A 61-year-old man complained of masticatory disturbance caused by loss of occlusal support and attrition in molar areas. Since the cause of disturbance was considered infraocclusion, occlusal vertical dimension was increased by insertion of occlusal splint-type treatment denture that covered occlusal surfaces of the remaining teeth and functional recovery was observed. Finally, a definitive denture was fabricated, which was supported by onlay-type rests on the worn occlusal surfaces of abutment teeth.

Discussion: Former vertical dimension was modified by insertion of the treatment denture, and based on it, final vertical dimension and design of the definitive dentures were determined. These steps facilitated good convalescence and satisfaction of the patient with the definitive denture. Tooth preparation for the bridges was able to be avoided by applying the onlay type rest.

Conclusion: Use of occlusal splint-type treatment dentures and application of onlay-type rest resolved the chief complaint regarding masticatory disturbance.

\section{Key words}

infraocclusion, vertical dimension, onlay-type rest, removable partial denture

明海大学歯学部機能保存回復学講座歯科補綴学分野

Division of Prosthodontics, Department of Restorative and Biomaterials Sciences, Meikai University School of

Dentistry

受付 : 2010 年 4 月 12 日/受理 : 2010 年 7 月 7 日

Received on April 12, 2010/Accepted on July 7, 2010 


\section{I，緒 言}

低位咬合の症例に対して補綴歯科治療を行う場合，顎 機能障害を誘発もしくは増悪させないよう慎重に対応す ることが重要である ${ }^{1,2)}$. 今回, 咬耗による低位咬合に 対して有床形態の咬合挙上用オクルーザルスプリント (以下，スプリントと略す）およびアンレー型レスト ${ }^{3)}$ を応用することで良好な結果が得られた部分床義歯補綴 の症例について報告する。

\section{II. 症例の概要}

患者 : 61 歳の男性.

初診日：平成 17 年 5 月 27 日.

主訴：上顎臼歯部欠損による咀嚼障害.

現病歴 : 数年前より臼歯部に欠損があったが, 食事に 支障がないため放置していた．約 2 力月前，这の硬質 レジン前装冠の脱離にて本院口腔診断科を受診し，検査 の結果， 5|27が保存不可能と診断され本院口腔外科 にて抜歯を行った。 その後, 臼歯部での咀嚼が困難とな り，口腔外科からの紹介により補綴科を受診した。

全身既往歴：気管支喘息（現在 n.p）花粉症（市販薬 服用).

特記事項：仕事で重い荷物を持つことが多く, クレン チングの自覚がある.

現症：欠損部位は75 $5 4 2 6 7 \longdiv { 6 5 | 6 }$ で Kennedy 分類は上顎 I 級 2 類, 下顎 III 級 1 類. Eichner 分類は B1 であり咬合支持域となる $4 \mid 45 \overline{4 \mid 45}$ に象牙質の露 出およびう蝕を伴う著明な咬耗が認められたが，歯髄反 応はすべて正常值であった。 また，凤に部分被覆冠が， 7ןに全部鋳造冠が装着されていた（図 1)。プラークコ ントロールは不良で，歯周組織の状態は全顎的に歯間乳 頭部の発赤および腫脹が認められたが， $4 \mathrm{~mm}$ 以上の 歯周ポケットおよび動摇は認められなかった。また，デ ンタルエックス線写真から著明な骨吸収は認められなか った（図 2)。最大開口量は $48 \mathrm{~mm}$ で疼痛はなく開閉 口路に著明な偏位は認められなかった。咬筋，側頭筋， 顎二腹筋前腹および後腹，顎関節部に触診による圧痛は 認められなかった。顎関節断層撮影では咬頭嵌合位にお いて両下顎頭ともほぼ関節窩内の中央に位置し，変形等 の異常所見も認められなかった。

診断:低位咬合を伴う上顎田歯部欠損による咀嚼障害.

治療方針：スプリントの装着により，主訴の改善と咬 合挙上による顎機能への影響を確認するとともに，歯周 治療，う蝕処置を併行して行い，得られた下顎位を中心

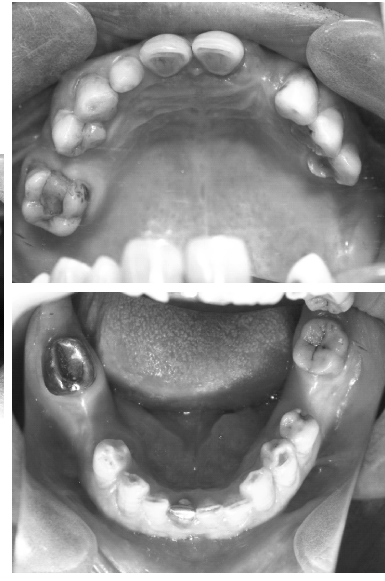

図 1 Intraoral view at the initial examination 初診時の口腔内写真

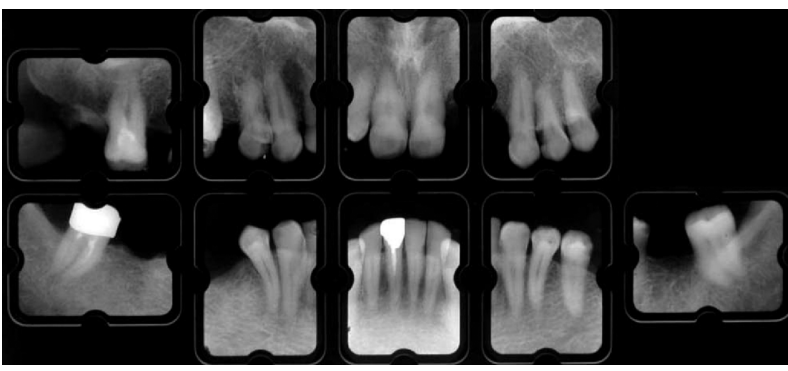

図 2 Dental radiographs at the initial examination 初診時のデンタル X 線写真

咬合位として最終補綴装置を製作することとした。

\section{III．治療内容と経過}

主訴である咀嚼障害の改善および咬合挙上による顎機 能への影響を検査することを目的とし上顎にスプリント を装着した。咬合挙上量は著明に咬耗している上顎小臼 歯部舌側咬頭の解剖学的形態の回復が可能な程度とし, 下顎安静位を越えないこと，嚥下が行えること等を確認 し前歯部で約 $3 \mathrm{~mm}$ とした。

スプリントの調整と併行して歯周初期治療（口腔衛生 指導・スケーリング）およびう蝕，咬耗による歯質欠損 へのコンポジットレジン充填を行った。 スプリントに与 える咬合様式は咬頭嵌合位では全歯均等接触とし側方運 動時のガイドは犬歯部に付与した（図 3).

スプリント装着後 3 カ月後において，スプリントを 装着した状態での咀嚼が可能であり，顎機能に異常のな いことが認められたため得られた下顎位を中心咬合位と して最終補綴装置を製作することとした。また，スプリ ントの対合歯咬合接触面には強い咬耗か認められ，患者 

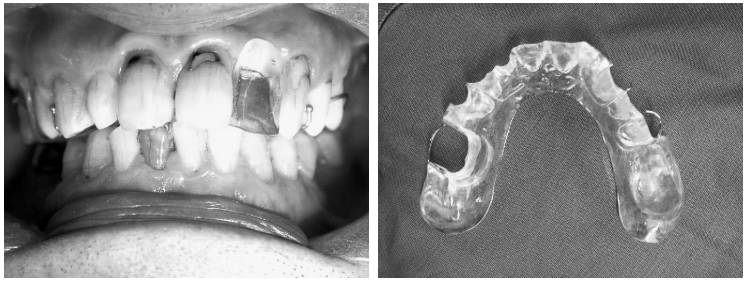

図 3 Occlusal splint オクルーザルスプリント

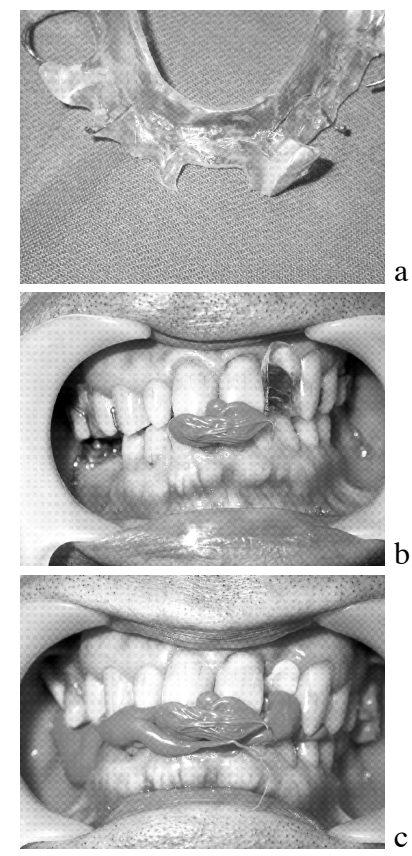

図 4 Maxillomandibular registration for definitive dentures (a: Partially cut out with occlusal splint. b: Partially maxillomandibular registration at anterior teeth. c: Final maxillomandibular registration)

最終義歯製作時の咬合採得（a：スプリントの部分 的な削除. $\mathrm{b}$ ：前歯部での部分的な咬合採得. $\mathrm{c}$ ：最 終的な咬合採得)

が強度のブラキシズムを有することが推察された。

最終補綴装置の選択にあたり咬耗歯が生活歯であるこ とと強度のブラキシズムを有することを考慮し，上顎に は咬耗部にアンレー型レスト ${ }^{3)}$ を設置した金属床による 部分床義歯を製作することとした，本症例のように咬耗 が著しく歯冠長か短い歯牙に固定性の補綴装置を装着す る場合，脱離を避けるためには根管内に維持を求めたポ ストの使用が避けられず，抜髄処置が必要となる．本症 例ではブラキシズム等の外力により歯根が破折する可能 性が高いことを考慮し生活歯のままで補綴装置が装着で きる方法を選択した。また，咬耗などの術後の変化に対
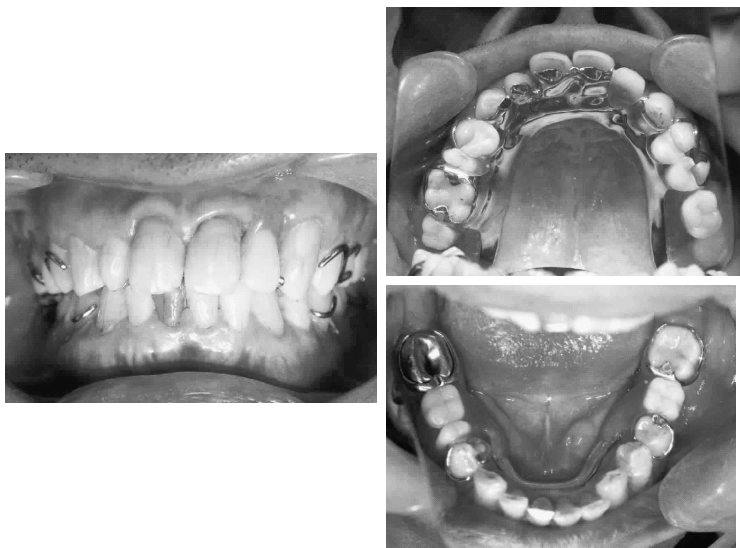

図 5 Intraoral view with definitive dentures inserted 最終義歯装着時の口腔内写真
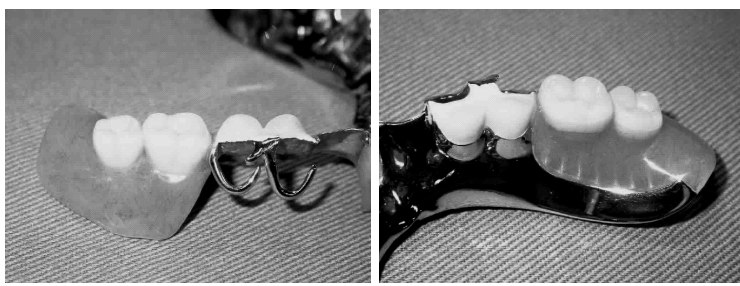

図 6 Onlay type rest of definitive dentures 最終義歯のアンレー型レスト部

応するためにアンレー型レスト咬合面には硬質レジンを 前装した。咬合挙上により前歯部には約 $3 \mathrm{~mm}$ クリアラ ンスが生じたため大連結子のメタルアップ部の延長によ り咬合接触を付与することとした，上顎金属床義歯の大 連結子にはスプリントの外形を参考にホーシュープレー トタイプを応用した。 なお下顎にはリンガルバーを応用 した両側処理によるレジン床義歯を製作することとした。 最終義歯は通法により前処置，印象採得ののち，スプ リントにより得られた下顎位を中心咬合位として咬合採 得した。その術式を図 $4 \mathrm{a} \sim \mathrm{c}$ に示す。スプリントの前 歯部を削除し前歯部のみの部分的な咬合記録を採得した (図 4a，b)。そののち，スプリントを外し，採得した前 歯部での咬合記録を介在させて最終的な咬合採得を行つ た（図 4c)。この術式によりスプリントで得られた下䫈 位を中心咬合位として咬合器上に再現し人工歯排列を行 った。蝻義歯試適時に咬合状態・異物感・発音等の検査 を行い，異常がないことを確認し義歯を完成，装着した （図 5，6)。なお，睡眠時ブラキシズム対策としてスプ リントの継続使用を指示し，6 カ月ごとのメインテナン スを継続していくこととした.

経過：義歯装着 5 カ月後に $7 \mid$ エーカースクラスプの 破折に伴う義歯の動摇による咀嚼障害を主訴に来院し 


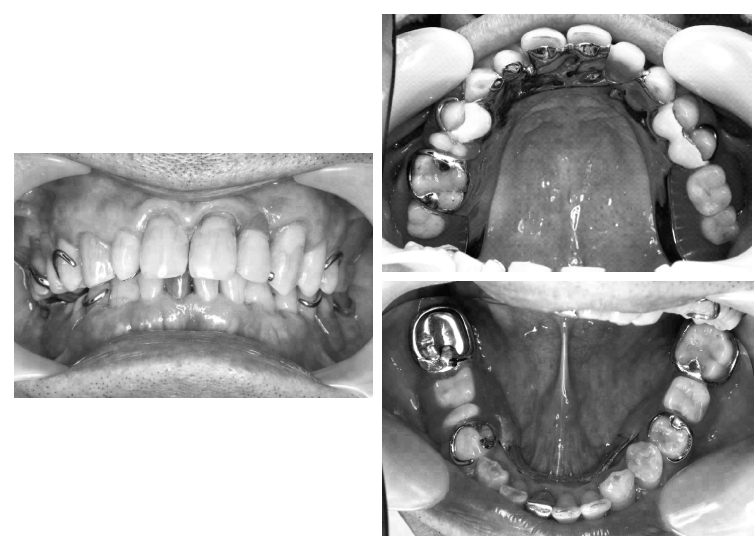

図 7 Intraoral views at 3 years after treatment 最終補綴装置装着後 3 年経過時の口腔内写真

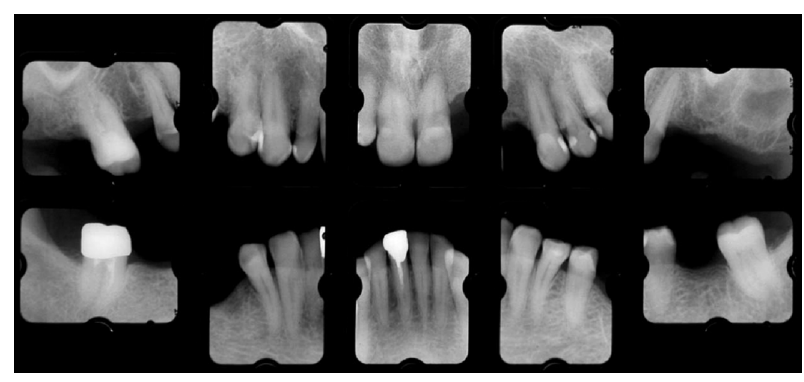

図 8 Dental radiographs at 3 years after treatment 最終補綴装置装着後 3 年経過時のデンタルX 線写真

た.クラスプは鉤脚部より破折していたため, クラスプ の再製作を行い義歯修理を行った。この際，脚部の表面 積を増加するとともにレストを大きくし $7 \mid \mathrm{Cr}$ の全周 を被う鉤尖のないリング状の鉤腕へと設計変更すること で支持・把持作用を増強した. 装着 3 年後のメインテ ナンス時に，4煩側のワイヤークラスプの破折を確認し たが, 自覚症状はなく, 咬合時の義歯の動摇もなかった ため，鋭縁部を研磨し，経過観察することとした。

以後, 6 カ月ごとのメインテナンスを継続している が，上顎義歯に設置したアンレー型レスト部やスプリン トの咬耗の進行が早いため, メインテナンス時に必要に 応じて修理を行い経過観察を行っている. 現在, 最終義 歯装着から 3 年 6 カ月が経過するが, 顎機能および歯 周組織に異常はなく，経過は良好である（図 7,8）。

\section{IV. 考 察}

本症例では咬合支持域は残存しているが，著明な咬耗 に伴う咬合高径の低下が問題となった，低位咬合を呈す る症例に対して, 補経歯科治療を行う場合は顎機能障害
を誘発もしくは増悪させないよう慎重に対応することが 重要である ${ }^{1,2)}$.

本症例では治療過程においてスプリントを応用するこ とにより，以下の利点が得られたと考えられる，1）主 訴である咀嚼障害の改善が早期に得られた。 2) 適切な 咬合挙上量の確認が最終補綴装置装着前に可能となつ た. 3）最終義歯の大連結子の設計においてスプリント の外形を参考にすることで, 装着後の異物感を最小限に することができた。 また，アンレー型レストを応用する ことにより，1）残存歯の歯質削除量を最小限に抑える ことができた，2）生活歯である支台歯の歯冠補綴を回 避することが可能となり, 顎機能障害を考慮した, 可逆 的な治療を実施することができた．3）アンレー型レス 卜咬合面に硬質レジンを用いることで，ブラキシズムに より生じる術後のトラブルへの対応が容易となった。

比較的早期にクラスプの破折が生じたこと，そしてア ンレー型レスト咬合面やスプリントの対合歯との咬合接 触面に生じる咬耗の進行が早いことからも強度のブラキ シズムを有することが推察されるため, 今後も顎機能お よび咬合状態等に対するメインテナンスを継続していく 必要があると考えられる.

\section{V. 結 論}

著しい咬耗に伴う咬合高径の低下が認められる症例に 対して, 有床形態のオクルーザルスプリントを治療用義 歯として応用し咬合挙上を行うとともに, 最終義歯とし て咬耗部にアンレー型レストを応用した部分床義歯を装 着した。その結果, 術後のトラブルへの対応が容易にな り，良好な結果が得られた。

\section{文献}

1）日本補経歯科学会. 顎機能障害の診療ガイドライン. 補 綴誌 2002; 46: 597-615.

2）藍 稔。顎機能異常と咬合. 東京：医歯薬出版；1999, $153-168$.

3) Osborne J. Lammie GA (津留宏道, 奥野善彦). Partial dentures 4th ed (オズボーンパーシャルデンチ ヤー. 東京: 医歯薬出版; 1977, 158-161.), 1974.

著者連絡先 : 山本 裕信 干 350-0283 埼玉県坂戸市けやき台 1-1 TEL: 049-279-2747 FAX: 049-279-2747 E-mail: hironobu@dent.meikai.ac.jp 